
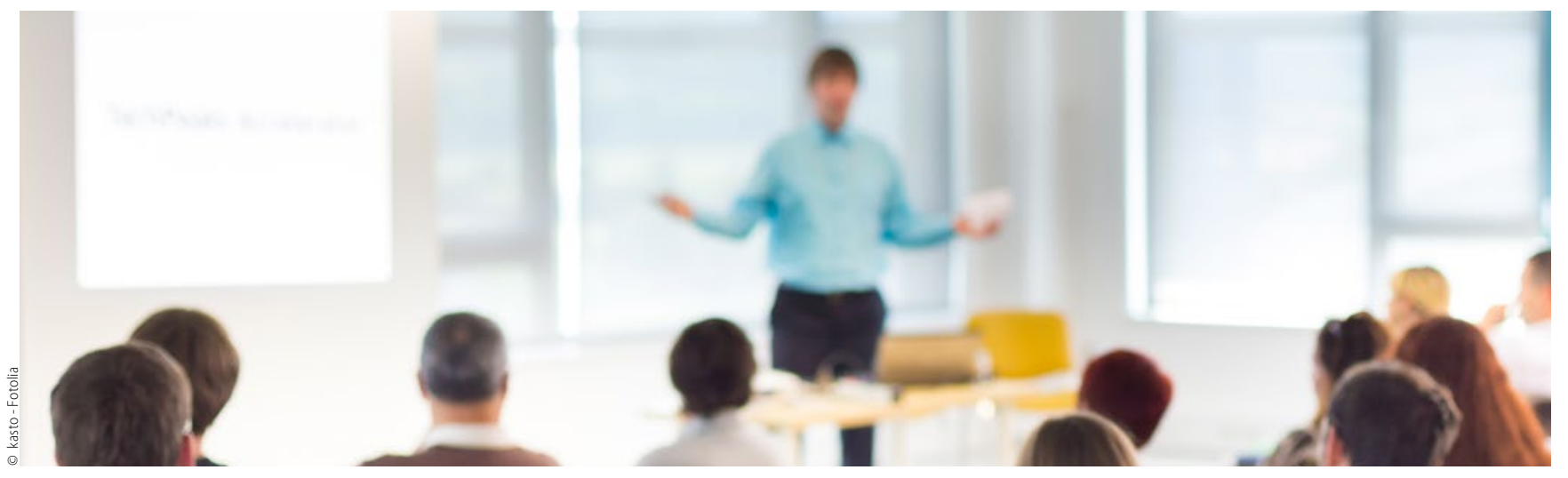

„young dentists meeting”

\title{
Tipps und Tricks für Berufseinsteiger
}

Vom 8. bis 9. April treffen sich in Bonn wieder zahnärztliche Berufseinsteiger zum traditionellen „young dentists meeting". Bei dem zweitägigen Seminar stehen verschiedene Themen auf dem Programm, die den Start in den Praxisalltag erleichtern. Diesmal heißen die Schwerpunkte: Startup Zahnarztpraxis und chirurgisches Basiswissen.

Nähere Infos und Anmeldungen unter www.young-dentists.de.

\section{Hier steht eine Anzeige.}

照 Springer 